Vol. 6(4), pp. 326-332, April 2014

DOI: 10.5897/IJ BC 2014.0693

Artic le Number. 1453A3046764

ISSN 2141-243X

Copyright (c) 2014

International Journal of Biodiversity

Author(s) retain the copyright of this a ric le

and Conservation

http://www.academic joumals.org/lJ BC

\title{
Ethnomedicinal studies on Bondo tribe of Malkangiri District, Odisha, India
}

\author{
Suchitra Rout ${ }^{1}$, Sitaram Prasad Panda ${ }^{2 *}$ and Hemant Kumar Patra ${ }^{1}$ \\ ${ }^{1}$ Post Graduate Department of Botany, Utkal University, Vanivihar, Bhubaneswar-751004, Odisha, India. \\ ${ }^{2}$ Mangrove Forest Division (WL), Rajnagar, Kendrapara, Odisha, India.
}

Received 12 January, 2014; Accepted 11 March, 2014

\begin{abstract}
Ethnomedicinal studies revealed the use of 34 angiospermic species by the Bondo tribe of Malkangiri district of Odisha. The traditional medicinal uses were observed to be wide spread and prevalent over modern medicine in the study area. In the present paper, plants for various diseases have been discussed togrther with dosage and mode of administration. Concurrently, correct name, family, local name are also provided for correct identification of the species.
\end{abstract}

Key words: Bondo, ethnomedicine, Malkangiri district, Odisha.

\section{INTRODUCTION}

In the past decade, there was renewed attention and interest in the use of traditional medicine globally. The World Health Organization (WHO) has pointed out that traditional medicine is an important contributor to its health goals. Today, according to the $\mathrm{WHO}$, as many as $80 \%$ of the world's people depend on traditional medicine and in India, 65\% of the population in the rural areas especially those residing in the remote forests mainly rely on traditional health practices as it is cost effective. Nowadays, the modern people are also using traditional medicinal practices as it has no side effects. Ethnobotany is a very broad field and it is an age old process starting from human civilization and medicine is one of its facet. In Odisha, 62 tribes are living in harmony with the nature in the mountainous forests of different districts. Out of these, 13 tribes are notified as Primitive Tribal Groups (PTG) while two tribes namely Bondo of Malkangiri and Dongaria Kandha of Kalahandi and Raygada districts are very rare and remote tribes under Particularly Vulnerable
Tribal Group (PVTG). The present study focused on Bondo tribes of Khairaput block of Malkangiri subdivision. The Bondo with a population of 5895 is one of the primitive tribes found only in the Malkangiri district of Odisha. They are confined to the hill ranges of Khairaput block of this district. Because of the long inhabitation of the tribe in this region, it is known as the Bondo country and the hills present in this region are known as the Bondo hills. The Bondo belongs to south Munda group of austraic family. They are sometimes referred to as the Bondo paraja. There are two important villages namely Mudulipada and Andrahal flanked by a distance of $14 \mathrm{~km}$ from each other where the Bondo tribes are living in harmony with nature.

In earlier times, Malkangiri was endowed with rich floristic diversity due to less population pressure coupled with dense forest coverage. In spite of rich and diverse floristic composition, Haines (1921-1925), the pioneer plant explorer for the state of Bihar and Orissa and Mooney

*Corresponding author. E-mail: situ.1979@gmail.com. Tel: +919437628624.

Author(s) agree that this article remain permanently open access under the terms of the Creative Commons Attribution License 4.0 International License 
(1950), the subsequent worker could not botanize this region thoroughly and as such various uses of plants by the natives were not documented in their respective treatise. There is considerable amount of genetic erosion in the plant wealth with the march of urbanization, establishment of factories coupled with the interferences of various categories such as shifting cultivation, illegal felling of tree species for timber and fuel, etc. Paradoxically, the magnitude of devastation is in increasing order during recent times, quite a good number of medicinal and food plants have already been wiped out. On the other hand, establishment of hospitals in remote areas has fascinated the aboriginal people to adopt the modern medical practices. Hence, traditional therapy is almost ignored.

Similarly, their food habit and utilization of plants and plant products for cultural activities have also been changed due to influence of modern civilization. Hence, critical identification as well as conservation of these fast disappearing elements is highly essential. Realizing this, Jain (1970-1971), Pal and Banerjee (1971), Sexena and Dutta (1975), Mudgal and Pal (1980), Subudhi and Choudhury (1985), Sahoo (1986) and Anonymous (1989, 1996) have made some sporadic reports on the ethnobotanical aspects.

\section{Study area}

Malkangiri is the southernmost district of Odisha. The district is named after its headquarters town Malkangiri. During the formation of Orissa province in 1936, Malkangiri was a 'Taluk' of Nabarangpur sub-division of Koraput district of Odisha. In 1962, it was upgraded to a sub-division of Koraput district and later on designated as a separate district. Malkangiri lies in between $17^{\circ} 45^{\prime} \mathrm{N}$ and $18^{\circ} 40^{\prime} \mathrm{N}$ latitudes and $81^{\circ} 10^{\prime} \mathrm{E}$ to $82.00^{\prime} \mathrm{E}$ longitude and situated at an elevation of 641 '(feet) from the mean sea level (Map 1). The district spreads over an area of $5791 \mathrm{sq} . \mathrm{km}$ (48. $43 \mathrm{~km}$ radius) as per the census of 2011. Malkangiri has a population of 613,192 , out of which 5895 are Bondo.

The area is of broken mountains intersected by large riverbeds and water courses. The altitude varies from 400 $\mathrm{m}$ near western side to $1200 \mathrm{~m}$ on the eastern side with mountain peaks and ridges. Sandy and clay type of soil is found to be predominant in the district. The climate of the major portions of the district is influenced by its varied elevation ranges. The minimum and maximum temperatures are 13 and $47^{\circ} \mathrm{C}$ in the month of December and May, respectively (Indian Meteorological Department, Bhubaneswar). Humidity is generally high especially in the monsoon and post monsoon months. The average annual rainfall is $1,700 \mathrm{~mm}$ (67 inches).

\section{METHODOLOGY}

Exhaustive seasonal field visits were undertaken (2010-2011) in the aegis of Post Graduate Department of Botany, Utkal University,
Bhubaneswar for collection of plants and their relevant information. The plants collected, have been identified in consultation with the regional floras (Haines 1921-1925; Saxena and Brahmam, 19941996) and monographs and preserved in the herbarium of the Post Graduate Department of Botany, Utkal University, Bhubaneswar. The information was gathered through oral interviews of the local tribal men, especially older persons, local medicine men and herbalists. During discussions with the tribal peoples, several data like local names, usable parts, medicine preparation methods, mode of application and dosage were recorded. The plants were arranged under respective diseases on which these are used along with family, local name and mode of preparation as well as administration. The medicinal uses of the species have also been confirmed with standard literatures viz. Agarwal and Ghosh (1985), Anonymous (1948-1972), Chopra et al. (1956), Kirtikar and Basu (1935), Satyavati et al. (1987), Saxena and Dutta (1975) and Warrier et al. (1994-1996).

\section{RESULTS AND DISCUSSION}

A total of 34 plant species belonging to 33 genera and 25 families were identified as being used for treatment of approximately 17 ailments or therapeutic indications including headache, toothache etc. (Table 1). Fabaceae, Caesalpiniaceae and Acanthaceae families had the largest number of plants used; and the largest numbers of preparations used were for dysentery and skin diseases. Mostly, leaves are used for preparation of medicines for different ailments. Water is used exclusively in the preparation of medicines. The use of Diospyros melanoxylon Roxb., Nyctanthes arbor-tristis L., Cassia fistula L., Holarrhena pubescens Wall. ex G.Don and Hemidesmus indicus R.Br. by the Bondo tribes for healing different ailments are recorded for the first time and marked with asterisk in Table 1.

\section{Conclusion}

Malkangiri, one of the richest botanical treasures in Odisha is under intense biotic pressure owing to forest fire, over exploitation of medicinal plants for drugs and conversion of forest to agricultural lands. These factors of degradation results not only in the depletion of certain valuable interesting medicinal taxa but also leads to substantial reduction in the density and genetic diversity of forest cover. This rapidly damages the natural habitats threatening the very survival of several indigenous species.

Presently, developing nations such as India have an imperative need of a systematic document on the traditional knowledge of various medicinal uses of plants in all autonomous areas or communities, many of which are still largely unexplored. Such documentation is necessary because older people are usually the only custodians of such information and the fast disappearance of traditional cultures and natural resources arising from urbanization and industrialization of such areas suggest that unrecorded information may be lost for ever. 


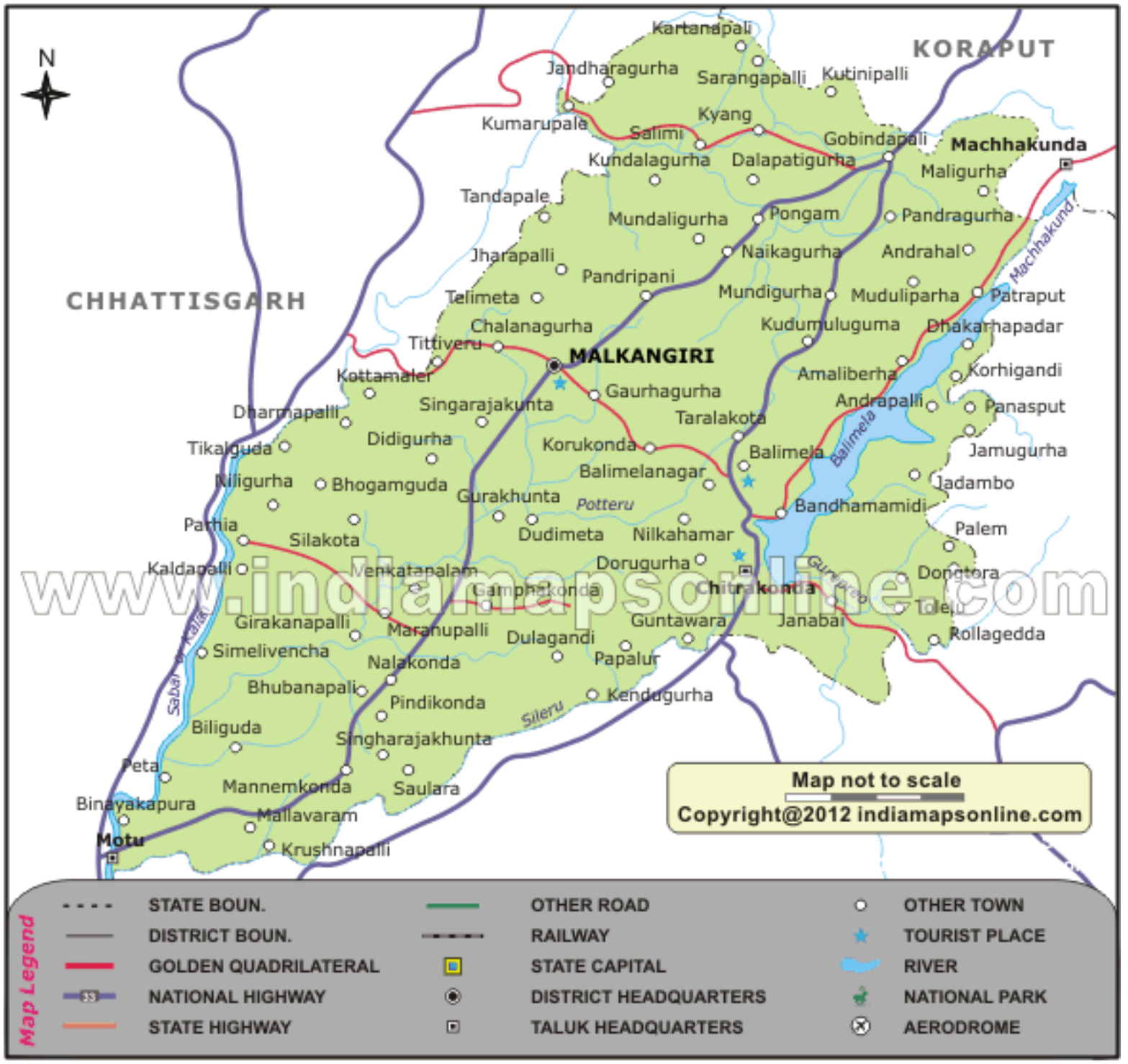

Map 1. Map of Malkangiri District of Odisha.

Table 1. Traditional uses of plants against various diseases.

\begin{tabular}{|c|c|c|c|}
\hline $\begin{array}{l}\text { Therapeutic indication } \\
\text { Botanical and Family name }\end{array}$ & Local name & $\begin{array}{l}\text { Plants parts } \\
\text { used }\end{array}$ & Medicinal preparation and dosage \\
\hline \multicolumn{4}{|l|}{ Abortifacient } \\
\hline $\begin{array}{l}\text { Abrus precatorius L. (Fabaceae) } \\
\text { (Figure 1) }\end{array}$ & Kaincha & Seeds & $\begin{array}{l}\text { Three seeds taken for } 4 \text { consecutive days to induce } \\
\text { abortion }\end{array}$ \\
\hline $\begin{array}{l}\text { Plumbago zeylanica L. } \\
\text { (Plumbaginaceae) }\end{array}$ & Sitaparu & Root & $\begin{array}{l}\text { Two grams of root power with water taken orally for } 2 \\
\text { times. }\end{array}$ \\
\hline \multicolumn{4}{|l|}{ Cough } \\
\hline $\begin{array}{l}\text { Adhatoda zeylanica Medik. } \\
\text { (Acanthaceae) }\end{array}$ & Basongo & Leaves & Decoction of seven leaves taken orally for one week. \\
\hline $\begin{array}{l}\text { Barleria prionitis L. } \\
\text { (Acanthaceae) }\end{array}$ & Tamresa & Leaves & $\begin{array}{l}15 \mathrm{ml} \text { of leaf juice mixed with honey given orally for } \\
\text { one week. }\end{array}$ \\
\hline
\end{tabular}


Table 1. Contd.

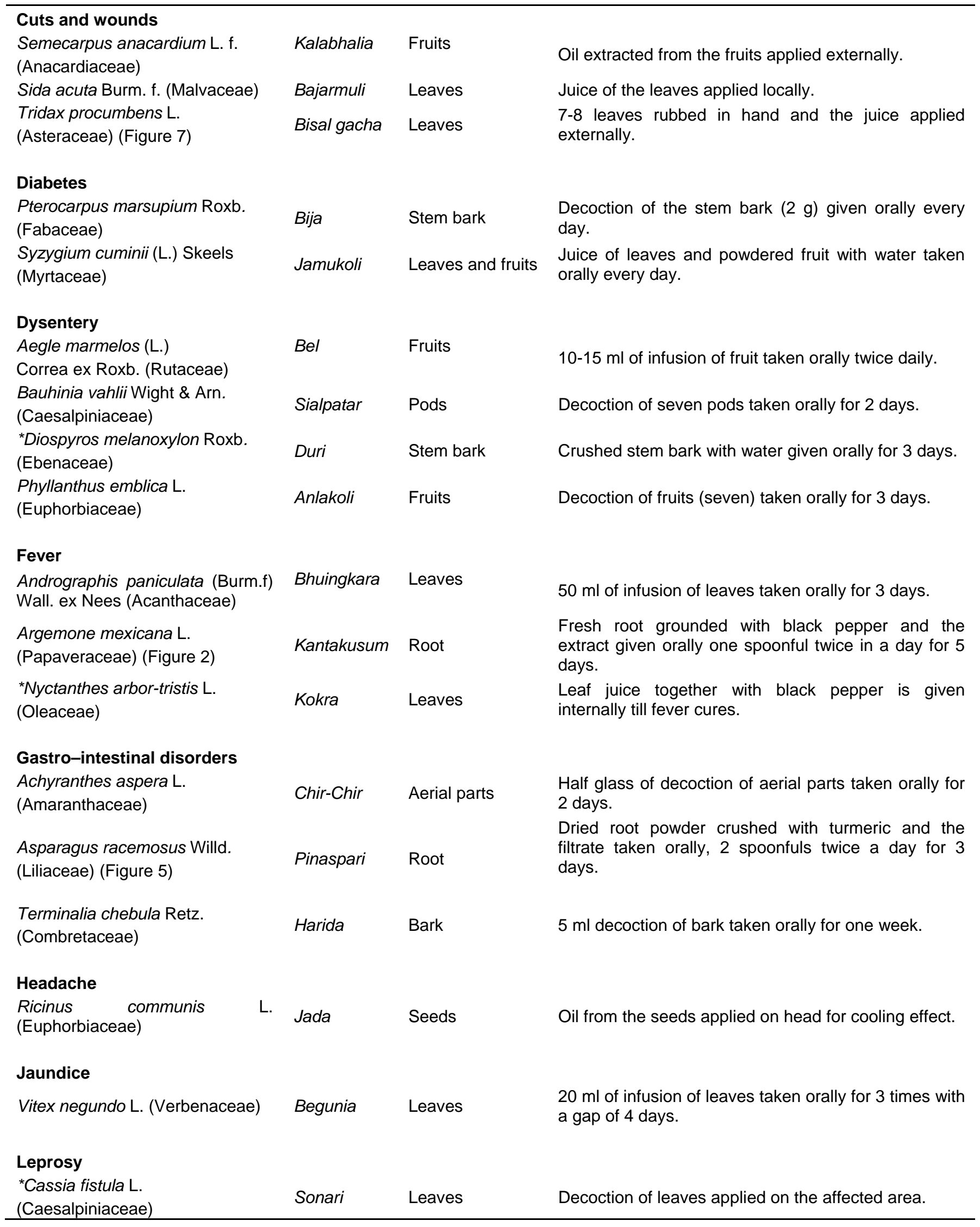


Table 1. Contd.

\begin{tabular}{|c|c|c|c|}
\hline $\begin{array}{l}\text { Costus speciosus (Koenig.) Sm. } \\
\text { (Zingiberaceae) }\end{array}$ & Keokanda & Rhizome & Paste of the rhizome with water applied locally. \\
\hline \multicolumn{4}{|l|}{ Liver disorder } \\
\hline $\begin{array}{l}\text { *Butea monosperema (Lam.) } \\
\text { Taub. (Fabaceae) (Figure 3) }\end{array}$ & Palaso & Leaves & A glass of leaf extract taken orally for 2 days. \\
\hline \multicolumn{4}{|l|}{ Rheumatic pain } \\
\hline $\begin{array}{l}\text { Holarrhena pubescens Wall. ex } \\
\text { G.Don (Apocynaceae) }\end{array}$ & Khucchi & Leaves & $\begin{array}{l}\text { Two to three leaves are attached with the latex of the } \\
\text { same plant over back bone and fomented externally. }\end{array}$ \\
\hline $\begin{array}{l}\text { Lantana camara L. } \\
\text { var. aculeata (L.) Mold. } \\
\text { (Verbenaceae) (Figure 6) }\end{array}$ & Nagiri & $\begin{array}{l}\text { Leaves and } \\
\text { flowers }\end{array}$ & Decoction of both parts given orally for 21 days. \\
\hline \multicolumn{4}{|l|}{ Skin diseases } \\
\hline $\begin{array}{l}\text { Azadirachta indica A. Juss. } \\
\text { (Meliaceae) }\end{array}$ & Nima & Leaves & $\begin{array}{l}\text { Crushed dried leaves with water applied locally till } \\
\text { cure. }\end{array}$ \\
\hline $\begin{array}{l}\text { Calotropis gigantea (L.) R. Br. } \\
\text { (Asclepiadaceae) (Figure 4) }\end{array}$ & Arakha & Root & Dried root powder sprayed locally. \\
\hline $\begin{array}{l}\text { Cassia tora L. } \\
\text { (Caesalpiniaceae) }\end{array}$ & Chhota Chakunda & Leaves & Leaf paste applied locally for 3 days. \\
\hline $\begin{array}{ll}\text { Mimosa } & \text { pudica } \\
\text { (Mimosaceae) }\end{array}$ & Lajuli & Root & $5 \mathrm{ml}$ of root juice applied locally for one week. \\
\hline \multicolumn{4}{|l|}{ Snakebite } \\
\hline $\begin{array}{l}\text { Strychnos nux-vomica L. } \\
\text { (Loganiaceae) }\end{array}$ & Kochila & Root & Root paste applied locally. \\
\hline \multicolumn{4}{|l|}{ Stomach pain } \\
\hline $\begin{array}{l}\text { Ocimum } \\
\text { (Lamiaceae) }\end{array}$ & Tulsi & Leaves & $\begin{array}{l}\text { A handful of leaves boiled in water and the infusion } \\
\text { taken orally till pain relief. }\end{array}$ \\
\hline \multicolumn{4}{|l|}{ Toothache } \\
\hline $\begin{array}{l}\text { *Hemidesmus indicus (L.) R. Br. } \\
\text { (Asclepiadaceae) }\end{array}$ & Chirmar & Root & $\begin{array}{l}\text { Root paste is applied on teeth or a piece of root is } \\
\text { crushed by teeth. }\end{array}$ \\
\hline
\end{tabular}

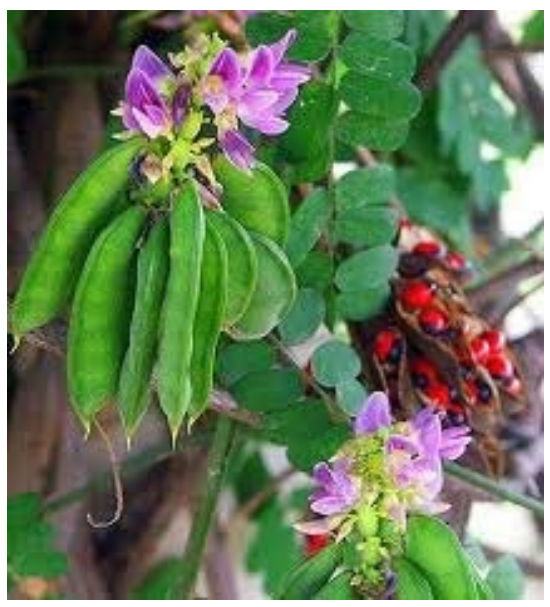

Figure 1. Abrus precatorius.

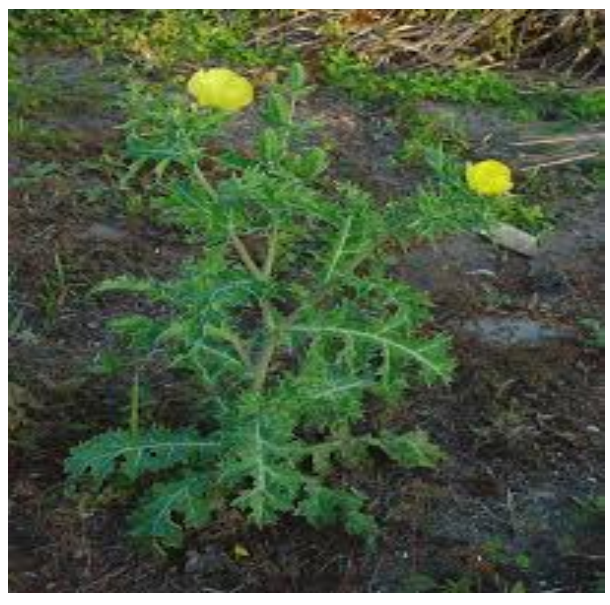

Figure 2. Argemone mexicana. 


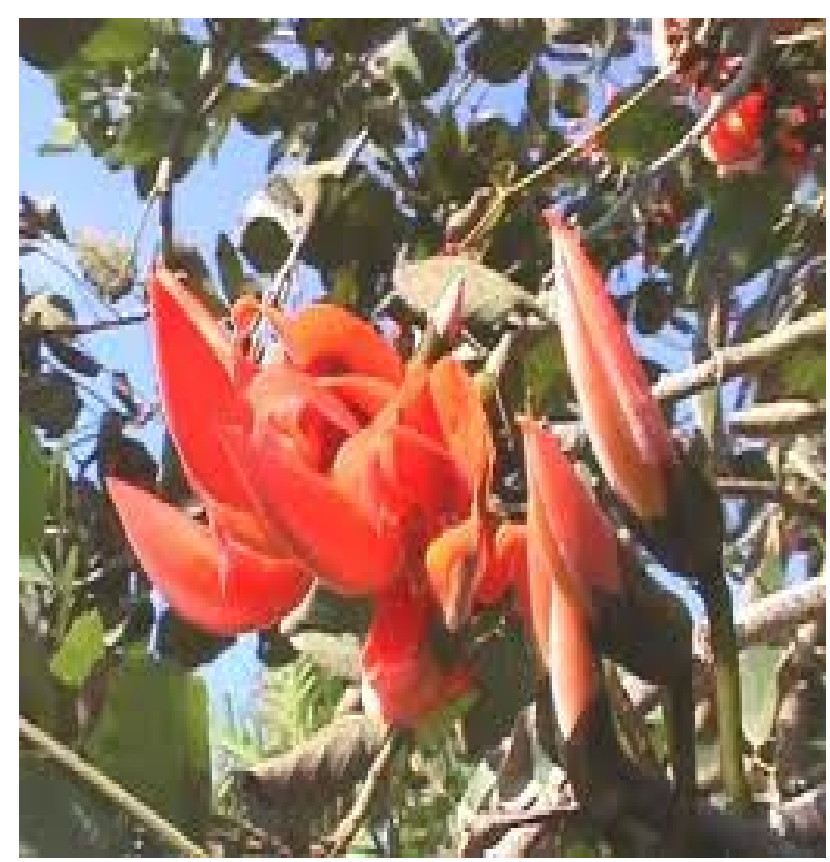

Figure 3. Butea monosperma.

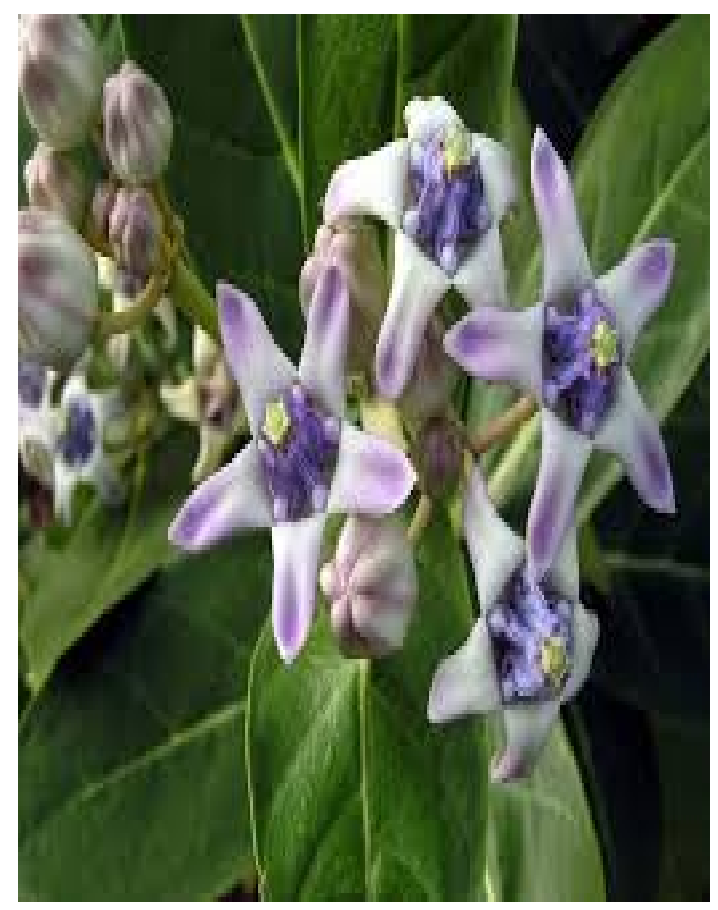

Figure 4. Calotropis gigantea

Documentation of plant materials used in traditional medicine could benefit general health care and promote forest conservation and ecological research. Such plants could also be incorporated into primary health care, as people generally feel safer with indigenous cures and also cost effective as compared to modern drugs. So

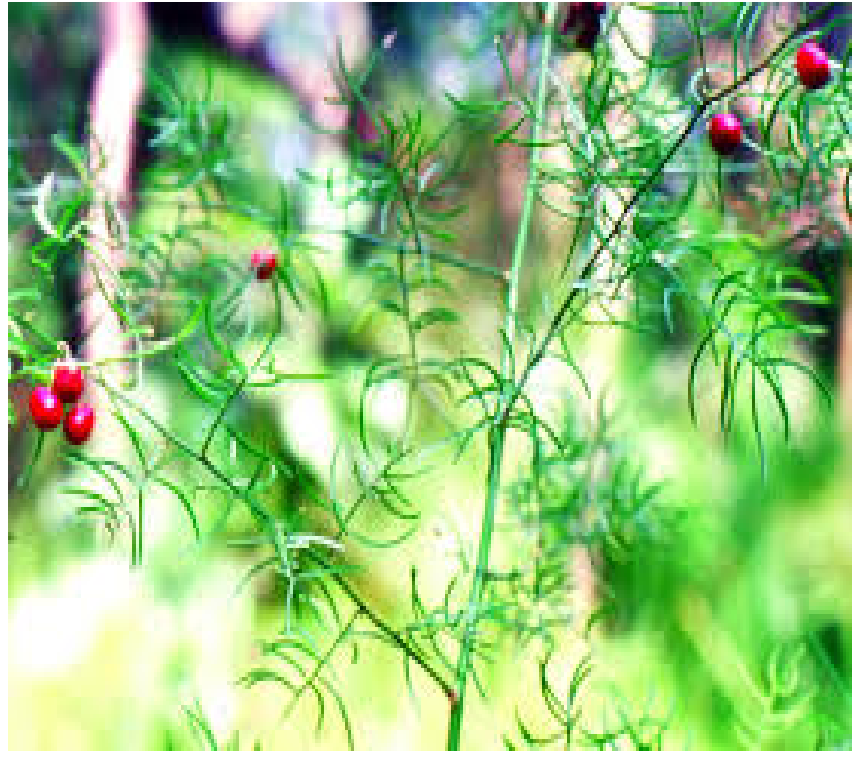

Figure 5. Asparagus racemosus.

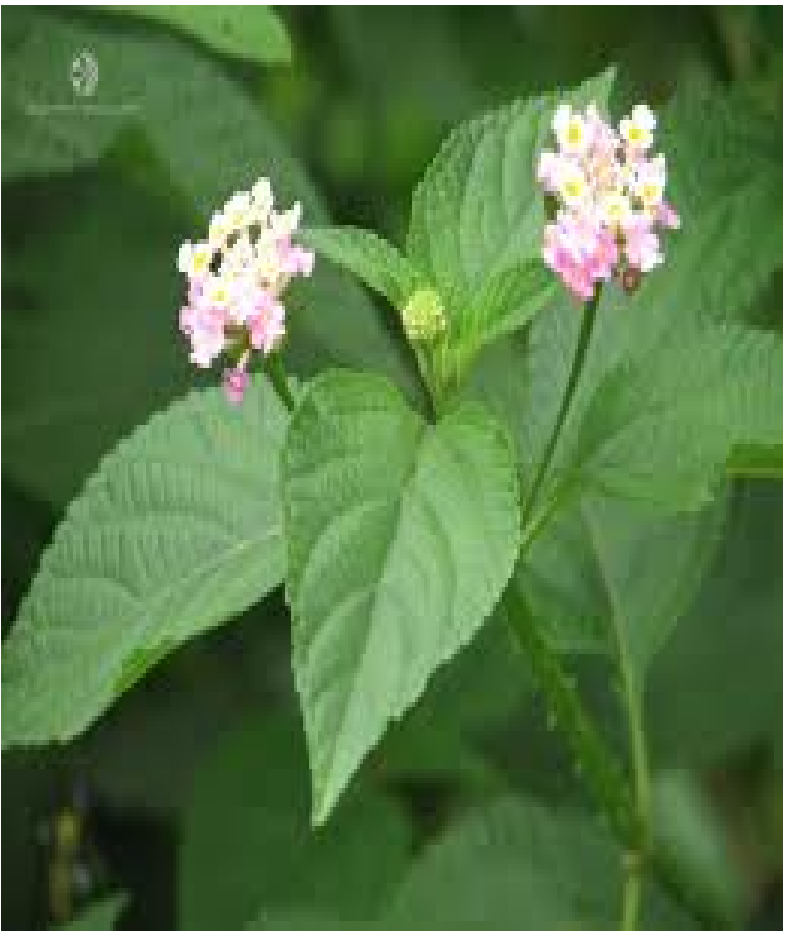

Figure 6. Lantana camara var. aculeatae.

this will pave way for conservation and to restore the genetic diversity.

\section{Conflict of Interests}

The author(s) have not declared any conflict of interests. 


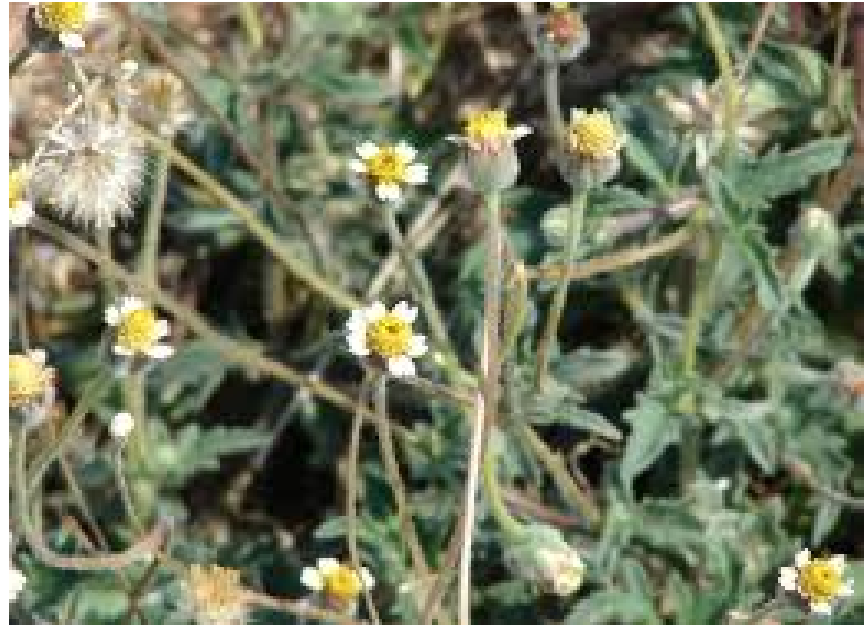

Figure 7. Tridax procumbens.

\section{ACKNOWLEDGEMENTS}

The authors are thankful to Prof. and Head, Post Graduate Department of Botany, Utkal University for providing necessary facilities. Thanks are also due to the local medicine men, vaidyas of Bondo tribes for their valuable information.

\section{REFERENCES}

Agarwal YS, Ghosh B (1985). Drug plants of India (Root Drugs) Kalyani Publishers, New Delhi.

Anonymous (1948-1972). Wealth of India (Raw materials), 9 vols, CSIR, New Delhi.

Anonymous (1989). Medico-Botanical Exploration of Puri District, Odisha, CCRAS, New Delhi.

Anonymous (1996). Medico-Botanical Exploration of Phulbani and Koraput District of Odisha.

Chopra RN, Nayar SL, Chopra IC (1956). Glossary of Indian Medicinal Plants, CSIR, New Delhi.
Haines HH (1921-1925). The Botany of Bihar and Orissa. 6 parts, London.

Jain SK (1970-1971). Some magico-religious beliefs about plants among Adibasis of Orissa 12(1-4):38-43.

Kirtikar KR, Basu BD (1935). Medicinal plants of India. Vol (1-2), ICMR New Delhi.

Mooney HF (1950). Supplement to the Botany of Bihar and Orissa, Catholic Press, Ranchi.

Mudgal V, Pal DC (1980). Medicinal plants used by tribals of Mayurbhanja (Orissa), 22(1-4):38-43.

Pal DC, Banerjee DK (1971). Some less known plant foods among the tribals of Andhra Pradesh and Orissa State. Bull. Bot. Surv. India. 13(3\&4):221-223.

Sahoo AK (1986). Plant Resources of Kandhamal district (Orissa) some suggestion to develop cottage industries in tribal localities, Orissa Review 43 (4):39-44.

Satyavati GV, Gupta AK, Tandon N (1987). Medicinal plants of India Vol.(1-2), ICMR, New Delhi.

Saxena HO, Brahman M (1994-1996). The flora of Orissa. Vol. (1-4) Orissa Forest Development Corporation, Bhubaneswar.

Saxena HO, Dutta PK (1975). Studies on the ethnobotany of Orissa. Bull. Bot. Surv. India 17 (1-4):124-131.

Subudhi HN, Choudhury BP (1985). Ethnobotanical studies in the district of Kandhamal (Orissa-1)-1 Bio-Sci. Res. Bull. 1(1-2):26-32.

Warrier PK, Nambiar VPK, Ramankutty C (1994-1996). Indian Medicinal Plants (Vol.1-5), Orient Longman Ltd., Madras. 